\section{Differentiated granites and critical metal mineralizations in Freixo de Numão W(Sn) district, Northern Portugal}

\author{
ANA GONÇALVES ${ }^{1,2}$, HELENA SANT'OVAIA ${ }^{1,2}$ AND \\ FERNANDO NORONHA ${ }^{1,2}$
}

${ }^{1}$ Faculty of Sciences, University of Porto

${ }^{2}$ Instituto de Ciências da Terra (Porto Pole)

Presenting Author: ana.goncalves@fc.up.pt

The geochemical signatures of the granite plutons outcropping in Vila Nova de Foz Côa area (Northern Portugal) coupled with fieldwork and ore mineralogy studies provided an important contribution for their emplacement, magmatic differentiation and relationships between the granite magmatism and $\mathrm{Sn}$ and $\mathrm{W}$ mineralizations. The study area is characterized by the occurrence of three small isolated circumscribed Variscan plutons (Numão, Freixo de Numão and Custóias) which intrude Lower Cambrian metasedimentary sequences from the Schist Greywacke Complex (SGC). Spatially associated with these plutons $\mathrm{W}, \mathrm{Sn}, \mathrm{W}(\mathrm{Sn})$ and $\mathrm{Sn}(\mathrm{W})$ deposits occur. The Numão pluton ( $c a .300 \mathrm{Ma}$ ) is constituted by five distinct granites (Figure 1 for detailed information): Cachão de Arnozelo (CAG), Numão (NG), Arnozelo (AG), Quinta da Silvã (QSG) and Geraldes (GG). The Custóias pluton (ca. $300 \mathrm{Ma}$ ) is composed by a small homogeneous granite, the Custóias granite (CG). The Freixo de Numão pluton $(\leq 299 \mathrm{Ma})$ is composed by two distinct granites: Freixo de Numão granite (FNG) and Frei Tomé granite (FTG). All granites are peraluminous with an average molecular $\mathrm{A} / \mathrm{CNK}$ ratios ranging between 1.2 and 1.40 . The petrography and geochemistry reveal granites with different differentiation degrees (Figure 2): $1^{\text {st }}$ group - the less evolved granite represented by $\mathrm{FNG} ; 2^{\text {nd }}$ group - the intermediate evolved granites represented by CAG, QSG and FTG; and $3^{\text {rd }}$ group - the most evolved granites composed by NG, AG, aplite and CG. The highest values of $\mathrm{Rb}, \mathrm{Nb}$ and $\mathrm{Sn}$ and the lowest of $\mathrm{Sr}, \mathrm{Zn}, \mathrm{Zr}, \mathrm{Ba}$ and Th allowed to distinguish Sn-bearing granites (AG, CG and aplites; Sn: 25 to $55 \mathrm{ppm}$ ). Two main mineralizing episodes are proposed: one responsible for $\mathrm{Sn}$ mineralizations in quartz and aplite veins and other responsible for the $\mathrm{W}$ mineralizations in quartz veins and skarns. It is considered that Sn mineralizations are associated with magmatic fractionation processes of "wet" peraluminous magmas related to Sn-bearing granites (Num and $\mathrm{CG})$. On the other side, the $\mathrm{W}$ mineralizations are associated with "dry" magmas which developed peraluminous biotite-rich, (FNG) that played a crucial heat source role.
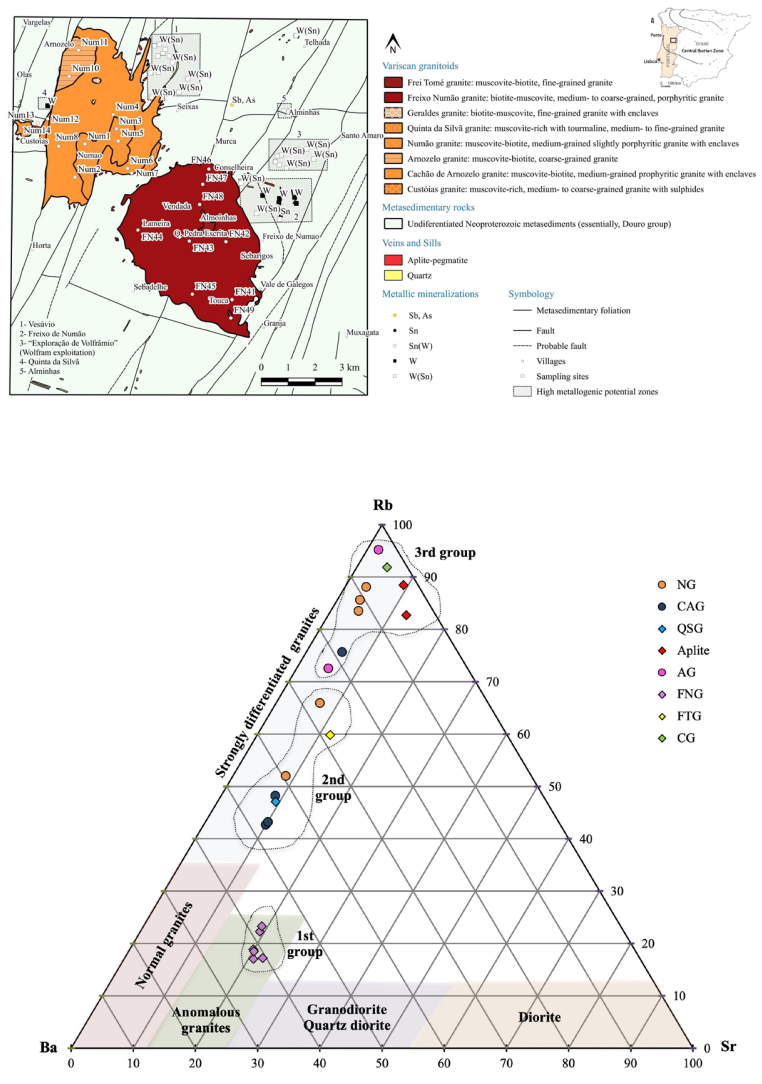